\title{
MENINGKATKAN KEMAMPUAN KEAKSARAAN RESEPTIF ANAK MELALUI PERMAINAN POLA SUKU KATA di TAMAN KANAK- KANAK NEGERI PEMBINA YOGYAKARTA
}

\author{
Oleh : \\ Amini \\ TK Negeri Pembina Umbulharjo Yogyakarta \\ Amini_ami@yahoo.co.id
}

\begin{abstract}
Abstrak
Permainan pola suku kata adalah salah satu teknik pembelajaran yang dilakukan guru untuk meningkatkan kemampuan keaksaraan reseptif anak dalam hal membaca sambil bermain di Taman Kanak- Kanak. Pengenalan keaksaraan ini dilakukan melalui permainan pola suku kata dengan media pola suku kata MDF dan menggunakan instrument dari buku panduan perkembangan keaksaraan, minat baca, dan permainan pola suku kata. Alat penilaian yang digunakan dengan menggunakan matriks indikator yang dibuat dalam bentuk cheklist, unjuk kerja dan dokumentasi. Subyek dalam penelitian ini adalah anak- anak kelompok B4 TK Negeri Pembina Yogyakarta yang berjumlah 23 anak terdiri dari 14 anak laki- laki dan 9 anak perempuan. Dari hasil penelitian menunjukkan adanya peningkatan kemampuan keaksaraan anak melalui permainan pola suku kata dengan media kartu huruf secara signifikan dibuktikan dengan data hasil awal 52,17\% meningkat menjadi 88,25\%.

Sedangkan data hasil minat baca dari 50,29\% meningkat 85,53\%. Hal ini dapat menunjukkan bahwa permainan pola suku kata dapat meningkatkan kemampuan keaksaraan reseptif anak.
\end{abstract}

Kata Kunci: Bermain Pola Suku Kata

Abstract
Syllable pattern game is one of the learning techniques used by teachers to improve the students' alphabetic receptive skill in reading letters while playing in kindergarten level. The alphabetic introduction is carried out through the syllable pattern game using MDF syllable pattern media and instrument from guidebook of alphabetic development, reading interest, and syllable pattern game. Assessment is done using indicator matrix made in the form of checklist, workbook, and documentation. Subjects in this research are 23 students in group B of TK Negeri Pembina Yogyakarta consisting of 14 boys and 9 girls. The research result showed that there is significant improvement of students' alphabetic skill through syllable pattern game using alphabet card media proved by the early data result $52.17 \%$ turned into $88.25 \%$ in the final result. The reading interest rate which was $50.29 \%$ in the early result data increased into $85.53 \%$. The research results illustrate that the syllable pattern game can improve the students' alphabetic receptive skill.

Keywords: Play, Syllable pattern

\section{PENDAHULUAN}

Perkembangan keaksaraan anak merupakan aspek utama yang sangat penting untuk meningkatkan kemampuan dan kreativitas anak. Seorang anak yang sudah dapat membaca biasanya dianggap anak yang mempunyai tingkat kecerdasan yang tinggi. Akan tetapi kecerdasan seseorang tidak dapat diukur hanya dengan bisa membaca saja. Seseorang dapat dikatakan 
mempunyai tingkat kecerdasan yang tinggi selain bisa membaca juga mampu mengolah kata secara komprehensif, mengekspresikan kata- kata dalam bahasa tubuh ( ucapan dan perbuatan) yang dapat dipahami oleh orang lain, mengerti setiap kata, mengartikan dan menyampaikannya secara utuh kepada orang lain, serta berargumentasi, meyakinkan orang melalui kata- kata yang diucapkannya.

Buku Pedoman Pengembangan Program Pembelajaran di TK, anak TK usia 5-6 tahun diharapkan bisa menyebutkan simbol- simbol huruf yang dikenal, mengenal suara huruf awal dari nama bendabenda yang ada disekitarnya, menyebutkan kelompok gambar yang memiliki bunyi/ huruf awal yang sama, memahami hubungan antara bunyi dan bentuk huruf, serta membaca nama sendiri dan menuliskan nama sendiri. Sedangkan dalam Buku Pedoman Pengembangan Berbahasa di TK, anak TK diharapkan mempunyai perilaku sehubungan dengan perkembangan tahap awal membaca antara lain mengekspresikan pendapat terhadap apa yang sudah dibaca, memdemonstrasikan cara yang benar dalam menggunakan sebuah buku, menikmati membaca dengan orang dewasa dan mau membaca, serta menyadari nama mereka.

Agar anak dapat melaksanakan tugas perkembangan sesuai dengan tahap perkembangannya. Bantuan dan bimbingan dari orang tua dan guru dapat memberikan rangsangan terhadap saraf- saraf otak anak agar dapat berkembang, mengingat kecerdasan membaca dapat meningkatkan kreativitas anak. Pada kenyataannya masih banyak dijumpai anak- anak yang belum mendapatkan stimulan yang semestinya, sehingga masih banyak anak yang belum tertarik untuk belajar membaca, bahkan mereka lebih cenderung senang bermain balok- balok atau yang lainnya. Sedangkan orang tua sendiri mempunyai keinginan anak harus sudah bisa membaca saat lepas dari Taman Kanak- Kanak. Apalagi jika ingin masuk ke SD yang favorit.

Berdasarkan pengamatan peneliti selama 3 bulan, di kelompok B4 TK Negeri Pembina Yogyakarta, ketika guru sedang mengajarkan bidang Pengembangan Bahasa tentang keaksaraan, misalnya; menyebutkan simbol- simbol huruf, mengenal suara huruf awal dan nama- nama benda yang ada di sekitarnya, membaca nama sendiri, sebagian besar anak- anak masih belum tertarik dan masih terkesan semaunya sendiri sehingga ketika ditanya ulang oleh guru mereka hanya geleng kepala pertanda tidak tahu. Sepertinya tidak bisa tersimpan dengan baik di memori anak.

Menurut peneliti hal ini juga bisa disebabkan metode yang digunakan guru dalam mengajarkan keaksaraan pada anak tidak menarik atau kurang pas dengan perkembangan anak. Karena selama ini guru terlalu minim memperoleh pelatihan tentang bermain seraya belajar, sehingga guru tidak mempunyai banyak variasi kegiatan dalam mengajarkan keaksaraan pada anak. Peneliti bekerja sama dengan Pusat Pendidikan Anak dan Lansia LPPM UNY dalam menyelenggarakan pengembangan permainan keaksaraan anak. Salah satu permainan keaksaraan yang dipergunakan untuk mengatasi permasalahan yang ditemui di kelas adalah permainan pola suku kata yang diciptakan oleh Musfiroh.

Dengan permainan pola suku kata diharapkan dapat meningkatkan perkembangan keaksaraan reseptif anak. Anak- anak akan belajar menyusun hurufhuruf dan menjadikannya kata- kata yang bermakna dibawah bimbingan guru. Misalnya, ba-da-ka atau la-ma-na dst. Anak tinggal menyusun huruf saja karena pola huruf sudah disiapkan guru. Bagi anakanak yang belum mengenal huruf, permainan ini mungkin mengasyikkan dan bisa memacu minat baca mereka. 
Berdasarkan permasalahan tersebut, peneliti melakukan penelitian tindakan kelas tentang perkembangan keaksaraan reseptif anak dalam membaca melalui permainan pola suku kata di TK Negeri Pembina Yogyakarta tahun 2011/2012.

\section{Kemampuan Keaksaraan Reseptif}

Keaksaraan bisa diartikan sebagai sesuatu yang berhubungan dengan bahasa. Keaksaraan sendiri menurut kamus bahasa Indonesia berasal dari kata dasar aksara yang artinya huruf. Segala sesuatu yang berhubungan dengan huruf bisa disebut keaksaraan baik berupa membaca ataupun menulis. Kemampuan keaksaraan reseptif adalah kemampuan anak dalam membaca huruf dan tulisan.

\section{Perkembangan Keaksaraan}

Buku Pedoman Pengembangan Berbahasa di Taman Kanak- Kanak (2007: 3) menekankan pada perkembangan keaksaraan anak pada usia 5-6 tahun seperti:

a. Mendengar dan Berbicara

Secara umum dalam kegiatan mendengar anak dapat: mendengarkan dengan sungguh- sungguh dan merespon dengan tepat; berbicara dengan penuh percaya diri; menggunakan bahasa untuk mendapatkan informasi dan untuk komunikasi yang efektif dan interaksi sosial dengan yang lain; menikmati buku, cerita dan irama; mengembangkan kesadaran bunyi.

b. Awal Membaca

Secara umum melalui kegiatan awal membaca diharapkan anak dapat; membentuk perilaku membaca; mengembangkan beberapa kemampuan sederhana dan keterampilan pemahaman;mengembangkan kesadaran huruf.

Sedangkan dalam Buku Pedoman Pengembangan Program Pembelajaran di TK, antara lain; nnak bisa menyebutkan simbol- simbol huruf yang dikenal; mengenal suara huruf awal dari nama bendabenda yang ada disekitarnya; menyebutkan kelompok gambar yang memiliki bunyi/ huruf awal yang sama; memahami hubungan antara bunyi dan bentuk huruf; serta membaca nama sendiri; menuliskan nama sendiri.

Dalam buku Menumbuhkembangkan Baca Tulis Anak Usia Dini ( Musfiroh, 2009: 28) tahap perkembangan membaca anak dikategorikan ke dalam enam tahap, yang tiap- tiap tahap mungkin terdiri dari 2 atau 3 subtahap.

a. Tahap Diferensiasi

Pada tahap ini anak memperhatikan tulisan dan membedakannya dengan gambar. Anak menyebut gambar sebagai gambar dan tulisan sebagai tulisan.

b. Tahap Membaca Pura-pura.

1) Tahap Atensi bahasa Tulis

Anak memperhatikan berbagai model tulisan di berbagai media yang dilihat dan tertarik dengan bentuk tulisan tertentu. Anak menyukai buku cetak dan membawa ke sana ke mari.

2) Tahap Membaca Diskursif.

Anak mengetahui bahwa tulisan dapat dilafalkan dan memiliki informasi. Anak "membaca " tanpa mempedulikan informasi visual yang ada. Anak benar- benar arbitrer (menentukan sendiri) kata -kata yang ingin diucapkan tanpa mempedulikan tulisan yang ada.

c. Tahap Membaca Gambar

Anak memperhatikan tanda- tanda visual seperti gambar tetapi belum menguasai simbol. Anak 'membaca' koran dengan melihat gambar, membaca label dengan memperhatikan barang dan gambarnya. Anak menjabarkan gambar/informasi visual lain dalam bentuk satu kalimat/atau lebih. 
d. Tahap Membaca Acak

1) Tahap Membaca Acak Total

Anak menanyakan tulisan yang menarik perhatiannya, seperti label, nama judul.

2) Tahap Membaca Semi Acak

Ketertarikan anak terhadap tulisan di televisi ( nama stasiun TV), nama toko, nama majalah, merk sepatu, merk alat elektonik sangat terlihat. Anak aktif bertanya dan cepat mengenali tulisan.

e. Tahap Lepas Landas

Tahap lepas terbagi atas tiga subtahap, yakni tahap mengeja huruf lepas, tahap mengeja silabel kata, dan tahap membaca lambat tanpa nada.

1) Tahap Mengeja Huruf Lepas

Anak dapat membaca dengan mengeja

kata- kata yang belum dikenal sebelumnya. Anak dapat menggabungkan huruf menjadi suku kata terbuka (tetapi terhambat dalam suku kata tertutup). Pada tahap ini anak sudah mulai memiliki minat pada buku cerita, simbol- simbol sekitarnya. Anak membaca apa saja yang ada di sekitarnya walaupun sering frustasi ketika perhatiannya terlalu terfokous pada huruf lepas.

2) Mengeja Silabel Kata

Anak dapat membaca dengan mengeja kata- kata baru. Anak dapat menggabungkan suku kata menjadi kata. Anak bisa mengeja suku terbuka tetapi lambatdalam suku kata tertutup. Pada tahap ini, anak- anak sangat peka terhadap kata- kata yang dikenal, terutama apabila kata- kata tersebut mirip atau mengandung namanya.

3) Membaca Lambat Tanpa Nada

Anak dapat membaca teks baru secara lambat tetapi relatif cepat untuk kata yang sudah dikenal. Anak tidak langsung dapat memahami apa yang dibaca, tetapi pengulangan dapat membantu mereka memahami tulisan pendek. Sementara itu, lagu kalimat juga belum diperoleh secara alamiah. Anak masih berfokus pada pelafalan teks.

f. Tahap Independen

Riset menunjukkan bahwa tahap independen dapat dikategorikan ke dalam dua tahap, yakni independen awal dan independen.

1) Tahap Independen Awal

Hasil bacaan masih lambat, tetapi anak dapat memahami apa yang dibaca. Sudah ada lagu kalimat (koma dan titik), meskipun belum sempurna . Tahap ini dikenal sebagai tahap hampir sempurna. Tahap ini ditemukan pada sebagaian kecil anak TK pedesaan dan beberapa anak TK perkotaan dengan fasilitas baca yang baik.

2) Tahap Independen

Hasil bacaan anak relatif cepat, sudah memiliki lagu dan nada yang tepat. Anak sudah menguasai komponen tanda baca dan makna teks juga sudah diperoleh. Fasilitas bacaan/ buku cerita yang menarik dimanfaatkan secara aktif oleh anak. Beberapa teks singkat pada surat kabar atau majalah akan dibaca keras- keras oleh anak.

Sedangkan dalam Buku Pedoman Pembelajaran Membaca dan Menulis Melalui Permainan di TK ( 2007: 4), ada lima tahapan perkembangan membaca, yakni;

1. Tahap Fantasi ( Magical stage)

Pada tahap ini anak mulai belajar menggunakan buku, dia berpikir bahwa buku itu penting, membolak- balik buku dan kadang- kadang anak membawa buku sesukanya. Pada tahap pertama ini, orang tua atau guru harus menujukkan model atau contoh tentang perlunya membaca, 
membacakan sesuatu pada anak , membicarakan buku pada anak.

2. Tahap Pembentukan Kosep Diri ( self concep stage)

Anak memandang dirinya sebagai pembaca, dan mulai melibatkan diri dalam kegiatan membaca, pura-pura membaca buku, memberi makna pada gambar atau pengalaman sebelumnya dengan buku, menggunakan bahasa buku meskipun tidak cocok dengan tulisan. Pada tahap kedua ini orang tua atau guru memberikan rangsangan dengan membacakan sesuatu pada anak . Orang tua atau guru hendaknya memberikan akses pada buku- buku yang diketahui anak- anak , melibatkan anak membacakan berbagai buku.

3. Tahap Membaca Gambar ( Bridging reading stage)

Pada tahap ini anak menjadi sadar pada cetakan yang tampak serta dapat menemukan kata yang sudah dikenal, dapat mengungkapkan kata- kata yang memiliki makna dengan dirinya, dapat mengulang kembali cerita yang tertulis, dapat mengenal cetakan kata dari puisi atau lagu yang dikenalnya serta sudah mengenal abjad. Pada tahap ketiga ini , orang tua dan guru membacakan sesuatu pada anak- anak, menghadirkan berbagai kosa kata pada lagu dan puisi, memberikan kesempatan menulis sesering mungkin.

4. Tahap Pengenalan Bacaan ( Take- off reader stage)

Anak mulai menggunakan tiga sistem isyarat (graphoponic,semantic, dan syntactic) secara bersama- sama . Anak tertarik pada bacaan, mulai mengingat kembali cetakan pada konteknya , berusaha mengenal tanda- tanda pada lingkungan serta membaca berbagai tanda seperti kotak susu, pasta gigi, atau papan iklan. Pada tahap keempat ini, orang tua dan guru masih tetap membacakan sesuatu untuk anak- anak sehingga mandorong anak membaca sesuatu pada berbagai situasi. Orang tua dan guru jangan memaksa anak, untuk membaca huruf secara sempurna.

5.Tahap Membaca Lancar ( Independent reader stage)

Pada tahap ini, anak dapat membaca berbagai jenis buku yang berbeda secara bebas. Menyusun pengertian dari tanda, pengalaman dan isyarat yang dikenalnya, dapat membuat perkiraan bahan- bahan bacaan. Pada tahap kelima ini, orang tua dan guru masih tetap membacakan berbagai jenis buku pada anak- anak . Tindakan ini akan mendorong agar dapat memperbaiki bacaannya. Membantu menyeleksi bahan- bahan bacaan yang sesuai serta membelajarkan cerita terstruktur.

Dari uraian di atas dapat peneliti simpulkan bahwa perkembangan keaksaraan reseptif anak dalam membaca mengalami berbagai tahapan perkembangan dan tidak dapat berlangsung begitu saja. Perkembangan keaksaraan reseptif anak dalam membaca sambil bermain sangatlah penting untuk dikembangkan guna merangsang otak untuk berpikir sehingga sel- sel saraf otaknya dapat berkembang secara maksimal.

\section{Permainan Pola Suku Kata \\ Pengertian Permainan Pola Suku Kata}

Pengertian permainan pola suku kata menurut Musfiroh ( 2011: 50), merupakan permainan yang mengandalkan kemampuan mengenal peta dan pola. Huruf- huruf yang ditata seperti pola, baik pola manik- manik dan ronce dapat dimanfaatkan sebagai latihan membaca secara terbimbing. Anakanak yang belum bisa membaca justru akan 
menata huruf sesuai sesuai dengan warnanya dan meminta orang dewasa untuk membacakan. Merah -kuning, merahkuning, merah kuning, misalnya merupakan contoh pola dari ba-da-ka-atau la-ma-na. Anak- anak akan menukarkan huruf dan menjadikannya kata- kata yang bermakna di bawah bimbingan guru.

Warna huruf dalam permainan ini sudah ditentukan. Anak hanya perlu membuat pola, nanti guru yang akan mengajak mereka membunyikan pola-pola tersebut.

\section{Karakteristik Permainan}

Permaian pola suku kata memiliki karakteristik sebagai berikut:

a. Setiap huruf memiliki jenjang pengenalan. Vokal dikenalkan terlebih dahulu baru kemudian konsonan dengan susunan sebagai berikut : vokal $(\mathrm{a}, \mathrm{i}, \mathrm{u}, \mathrm{e}, \mathrm{o})$, konsonan $(\mathrm{b}, \mathrm{d}, \mathrm{k}, \mathrm{l}, \mathrm{m}, \mathrm{n}, \mathrm{s})=$ merah, konsonan $(\mathrm{g}, \mathrm{h}, \mathrm{j}, \mathrm{p}, \mathrm{r}, \mathrm{t})=$ hijau, konsonan $(\mathrm{c}, \mathrm{f}, \mathrm{w}, \mathrm{y})=$ oranye, konsonan ( $\mathrm{v}, \mathrm{z}, \mathrm{x}, \mathrm{q})=$ biru.

b. Vokal a berwarna kuning, i berwarna putih,u berwarna pink, e berwarna hijau muda, dan o berwarna biru muda; konsonan urutan kedua semua berwarna merah; konsonan urutan ketiga berwarna hijau; konsonan keempat berwarna oranye atau ungu, dan konsonan kelima berwarna biru.

c. Anak membuat pola dengan melihat warna, guru mendampingi untuk membacakan. Anak bermain dengan 1 vokal dan 1 deret konsonan, hingga semua vokal habis.

d. Setelah dapat mengenali pola suku terbuka, anak TK B dapat dikenalkan dengan pola suku kata tertutup.

e. Kemahiran dalam pola suku kata dapat ditingkatkan ke bentuk kata dengan tetap didampingi guru hingga anak dapat menunjukkan kemandirian.

\section{Komposisi Pola}

Pola disusun berdasarkan pola- pola tertentu sehingga menghasilkan pola suku

terbuka sembarang, pola suku terbuka tetap,pola suku tertutup sembarang, pola suku tertutup tetap, dan pola kata.

a. Pola suku terbuka sembarang

Pola suku terbuka sembarang terdiri atas huruf-huruf dengan warna gelap terang tanpa memperdulikan huruf. Konsonan - vokal, misalnya, diisi merah kuning. Maka anak dapat membuat pola dengan -ba, da, ka, la, ma, na, secara bergantian. Guru membacakan pola yang dibuat anak.

b. Pola suku terbuka tetap

Pola suku kata ini dibuat anak sesuai huruf. Anak masih terbantu dengan warna. Konsonan - vokal, misalnya, diisi bi atau merah putih, maka anak tidak lagi menjajar konsonan $b$ merah dan vocal i yang putih. Anak tetap manata bi, bi, bi. Anak juga bisa menyusun pola suku yang sama.

c. Pola suku tertutup sembarang

Pola suku tertutup sembarang terdiri atas huruf- huruf dengan warna gelap, terang, gelap tanpa memperdulikan huruf konsonan. Konsonan-vocalkonsonan, misalnya diisi merah-pinkhijau, maka anak dapat membuat pola dengan - bug, duh, sup, sur, dan seterusnya. Guru membacakannya.

d. Pola suku tertutup tetap

Pola suku kata ini dibuat anak sesuai pola huruf. Pola gelap-terang- gelap harus diisi dengan huruf-huruf yang sama, seperti bug, bug, bug, dur,dur,dur, sup, sup, sup. Anak tidak begitu saja membuat suku kata berdasarkan unsur warna huruf tetapi benar-benar berdasarkan unsur huruf.

e. Pola kata

Setelah anak dapat bermain suku terbuka tetap dan suku tertutup tetap, 
anak sebenarnya telah siap membuat pola kata. Anak mulai dapat membaca sendiri kata yang dibuat berdasarkan suku katanya.

Dari uraian di atas dapat disimpulkan bahwa permainan pola suku kata dapat dilakukan oleh guru untuk mengenalkan huruf pada anak TK dan dapat digunakan sebagai metode untuk mengajarkan membaca pada anak melalui bermain.

\section{METODE PENELITIAN}

Jenis Penelitian ini adalah Penelitian Tindakan Kelas (PTK). Subyek penelitian ini adalah anak kelompok B4 TK Negeri Pembina Yogyakarta yang berjumlah 23 anak. Sebagai kolaboratornya adalah guru sejawat.

Penelitian ini di mulai bulan Juli Nopember 2011 dengan menggunakan model Kurt Lewin yang terdiri dari empat komponen yang kemudian dikembangkan oleh Kemis dan Mc Taggart yang dikutip oleh Suharsimi ( 2010 : 132). Yaitu perencanaan, tindakan, observasi dan refleksi yang dilakukan dua siklus.

Waktu yang digunakan untuk melakukan pengamatan adalah selama 3 bulan, diawali pada tanggal 27 Juli sampai 2 September 2011. Sedangkan tindakan yang dilakukan pada siklus I yaitu pada tanggal 26 September hingga 20 Oktober 2011. Setiap season ada 4-5 anak yang diberi tindakan.

Begitu pula pada siklus II dilakukan 7 kali pertemuan tanggal 31 Oktober sampai 24 Nopember 2011. Setiap season 3-4 anak yang diberi tindakan.

Metode yang dipergunakan adalah metode observasi, metode penugasan, dan dokumentasi. Instrumen yang dipergunakan adalah instrumen perkembangan keaksaraan, instrumen penilaian minat baca, instrumen permainan pola suku kata dan catatan lapangan. Dalam penelitian ini alternatif jawaban tiap item untuk instrumen kemampuan keaksaraan anak, ada tiga kategori jawaban "jarang" dg skor 1, "sering" dengan skor 2 dan "selalu" dengan skor 3.

Setelah instrumen selesai diisi maka penelti dan kolaborator tinggal menganalisis hasilnya. Data yang telah diperoleh dihitung kemudian dipersentase. Dengan demikian dapat diketahui sejauh mana peningkatan yang dicapai dalam pembelajaran . Hasil analisis data dan observasi kemudian disajikan secara diskriptif.

\section{HASIL PENELITIAN DAN PEMBAHASAN}

Berdasarkan hasil pengamatan yang dilakukan, guru sering mengalami beberapa kendala diantaranya adalah ketika anak diberi kesempatan untuk membaca buku cerita bergambar, hanya beberapa anak saja yang senang dan bisa membaca buku. Hal ini disebabkan anak masih senang bermainmain dan tidak tertarik dengan kegiatan membaca. Untuk itu guru berkolaborasi dan berdialog dengan kolabolator untuk melaksanakan tindakan yang akan dilakukan guna mengemas dan merencanakan kegiatan membaca menjadi lebih menarik. Mulai dari membuat RKH, menyusun instrumen dan membuat media pembelajaran serta mengamati perilaku anak.

\section{Gejala Awal atau Pra Tindakan}

Dari data hasil pengamatan perkembangan keaksaraan pra tindakan diperoleh nilai sebesar 52,17\% Sedangkan hasil minat baca sebesar $50,29 \%$.

Data ini dapat dianalisis bahwa tingkat perkembangan keaksaraan anak masih rendah.

\section{Siklus 1}

Pada tahap ini diawali dengan pengenalan kegiatan permainan pola suku 
kata dengan media kartu huruf kepada siswa, dilanjutkan dengan penyusunan langkah sesuai RKH yang digunakan sebagai acuan dalam pelaksanaan pembelajaran siklus 1. Kegiatan permainan pola suku kata dilakukan satu kali tatap muka dalam satu pertemuan dengan jumlah anak 4-5 anak pada kegiatan inti. Siklus 1 dilakukan sebanyak 5 kali pertemuan.

Pelaksanaan Permainan Pola Suku Kata

Kondisikan 4-5 anak duduk di kursi .

1)Anak menyusun huruf- huruf tersebut dengan pola suku terbuka sembarang lalu guru membacakanya; 2) Anak membuat pola suku tertutup sembarang; 3) Anak pola suku terbuka tetap; 4) Anak membuat pola suku kata terbuka dan dapat mengeja sebagian; 5) Anak membuat pola suku tertutup dan tetap, dapat mengeja sebagian; 6) Anak membuat pola suku tertutup dapat mengeja; 7) Anak membuat pola kata tetap; 8) Anak membuat pola kata sendiri dan dapat membacanya; 9) Anak melanjutkan kata kartu guru dan dapat membacanya.

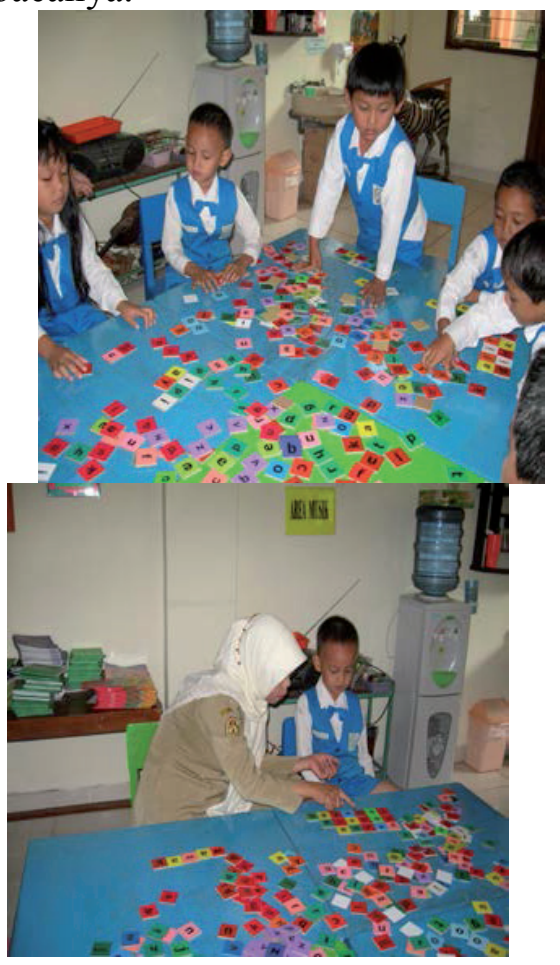

Demikian seterusnya hingga mencapai 4-5 anak bergantian melakukan permainan pola suku kata dalam satu kali tatap muka dalam satu kali pertemuan.

Pada awalnya saat guru memberikan contoh cara bermain pola suku kata dengan media kartu huruf, anak- anak sangat tertarik dan sangat antusias melihat warna- warna huruf tersebut. Guru merasa kuwalahan ketika banyak anak yg ingin mencoba dan guru hanya menunjuk beberapa anak saja. Anak yang tidak ditunjuk merasa kecewa. Sedangkan anak- anak yang ditunjuk merasa senang sekali karena bisa mencoba permainan pola suku kata tersebut. Guru memberi nasehat pada anak- anak yang tidak ditunjuk hari itu agar tidak kecewa karena semua pasti akan mencoba hanya beda harinya saja. Awalnya anak-anak merasa senang dengan huruf- huruf tersebut hingga tidak disusun tetapi dikelompokkelompokkan berdasarkan warnanya. Hurufhuruf tersebut di susun atau ditumpuk menurut warnanya. Guru mengamati perilaku anak tersebut sambil mencatat kejadian tersebut.

Pada saat urutan ke 5, ketika guru membacakan pola huruf yang disusun anak, anak tersebut mulai jenuh karena gilirannya untuk dibacakan guru terlalu lama dan guru pun juga merasa letih karena harus duduk secara berputar untuk membaca dan mendampingi anak dalam membacakannya.

Berdasarkan hasil pengamatan siklus 1, diperoleh hasil perkembangan keaksaraan sebesar $66,92 \%$. Sedangkan hasil minat baca $62,31 \%$. Artinya setelah diberi tindakan telah mengalami peningkatan perkembangan keaksaraan dibanding pada kondisi awal yaitu $14,74 \%$, minat baca meningkat menjadi sebesar 12,01\%. Masih jauh dari harapan guru. Hasil permaian pola suku kata diperoleh nilai total $47,18 \%$. 


\section{Siklus II}

Rencana tindakan pada siklus II disusun berdasarkan hasil analisis dan refleksi pada siklus I yaitu masih banyak anak yang merasa jenuh menunggu giliran dibacakan oleh guru dan guru juga merasa lelah harus berputar terus.

Pelaksanaan Permainan Pola Suku Kata siklus II sama dengan siklus I.

Kondisikan 3-4 anak duduk di kursi.

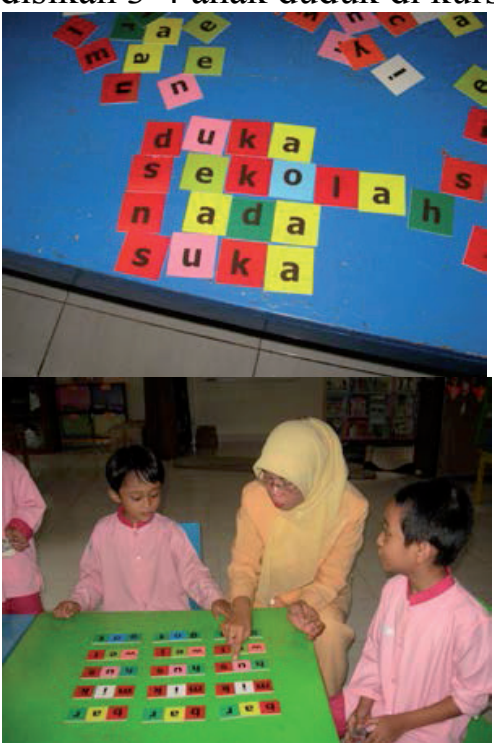

Demikian seterusnya hingga mencapai 3-4 anak bergantian melakukan permainan pola suku kata dalam satu kali tatap muka dalam satu kali pertemuan.

Pada saat guru akan memberikan contoh kembali cara bermain pola suku kata dengan media kartu huruf, anak- anak mengatakan "“ Tidak usah diberi contoh, $\mathrm{Bu}$. Kami sudah bisa, cepat to Bu". Anak- anak sudah tidak sabar lagi ingin segera bermain pola huruf tersebut. Anak- anak sudah tidak berebut lagi karena sudah tahu gilirannya kapan saatnya ia bermain. Tidak semua anak seperti itu, akan tetapi sudah ada peningkatan beberapa anak lagi jika dibanding dengan siklus 1 yang sudah dapat menyusun huruf- huruf tersebut hingga menjadi kata- kata yang bermakna dan dapat membacanya. Dengan jumlah anak 3-4 setiap tatap muka, guru sudah tidak kuwalahan lagi untuk membacakannya.

Berdasarkan hasil pengamatan siklus 2, diperoleh hasil perkembangan keaksaraan sebesar $88,40 \%$. Sedangakan hasil minat baca sebesar $85,67 \%$.

\section{PEMBAHASAN}

Berdasarkan analisis data, dapat disimpulkan bahwa pencapaian target yang diharapkan dapat tercapai. Berbagai kendala yang dihadapi guru terutama dalam hal mengembangkan keaksaraan reseptif anak dalam membaca sambil bermain dapat dilaksanakan oleh anak- anak. Keaksaraan reseptif anak mulai mengalami peningkatan terutama dalam minat baca dan permainan pola suku kata.

Dari hasil pelaksanaan permainan pola suku kata dapat disimpulkan bahwa :

a. Pada perkembangan keaksaraan kondisi awal sebesar 612 atau $52,17 \%$ meningkat menjadi 785 atau $66,92 \%$ dan meningkat lagi menjadi 1037 atau $88,40 \%$ I. Artinya telah terjadi peningkatan sebesar $14,75 \%$ (dari $52,17 \%$ menjadi $66,92 \%$ ) pada siklus I, dan sebesar $21,48 \%$ ( dari $66,92 \%$ menjadi $88,40 \%$ ) pada siklus II.

b. Perkembangan minat baca dari kondisi awal sebesar 590 atau $50,29 \%$ meningkat menjadi 731 atau $62,31 \%$, dan meningkat lagi menjadi 1005 atau $85,67 \%$. Artinya telah terjadi peningkatan sebesar $12,02 \%$ (dari $50,29 \%$ menjadi $62,31 \%$ ) pada siklus I, dan sebesar 23,36\%( dari $62,31 \%$ menjadi $85,67 \%$ ) pada siklus II. 
Jurnal Pendidikan Anak, Volume 5, Edisi 1, Juni 2016

\begin{tabular}{|c|c|c|c|c|}
\hline \multicolumn{2}{|c|}{$\begin{array}{l}\text { Tabel1.Rekapitulasi } \\
\text { Keaksaraan }\end{array}$} & \multicolumn{3}{|c|}{ Perkembangan } \\
\hline \multirow{2}{*}{ No } & \multirow{2}{*}{ Responden } & \multicolumn{3}{|c|}{ Skor Hasil Tindakan } \\
\hline & & $\begin{array}{c}\text { Pra } \\
\text { Tindakan }\end{array}$ & $\begin{array}{c}\text { Siklus } \\
\text { I }\end{array}$ & $\begin{array}{c}\text { Siklus } \\
\text { II }\end{array}$ \\
\hline 1 & $\begin{array}{lr}\text { Anak } & \text { mengikuti } \\
\text { instruksi } & \text { kegiatan } \\
\text { kelas } & \\
\end{array}$ & 34 & 45 & 66 \\
\hline 2 & $\begin{array}{l}\text { Anak } \\
\text { menyelesaikan } \\
\text { tugas }\end{array}$ & 36 & 42 & 61 \\
\hline 3 & $\begin{array}{l}\text { Anak tampak } \\
\text { bersemangat }\end{array}$ & 40 & 49 & 64 \\
\hline 4 & $\begin{array}{l}\text { Anak } \\
\text { mengembangkan } \\
\text { kegiatan mandiri }\end{array}$ & 36 & 46 & 58 \\
\hline 5 & $\begin{array}{l}\text { Anak aktif dalam } \\
\text { kelompok }\end{array}$ & 37 & 48 & 63 \\
\hline 6 & $\begin{array}{l}\text { Anak bertanya } \\
\text { kepada teman }\end{array}$ & 47 & 51 & 61 \\
\hline 7 & Perkembangan BTP & 41 & 51 & 63 \\
\hline 8 & Keaksaraan reseptif & 37 & 45 & 54 \\
\hline 9 & $\begin{array}{l}\text { Membuat pola suku } \\
\text { terbuka sembarang }\end{array}$ & 37 & 46 & 65 \\
\hline 10 & $\begin{array}{l}\text { Membuat pola suku } \\
\text { tertutup sembarang }\end{array}$ & 36 & 51 & 63 \\
\hline 11 & $\begin{array}{l}\text { Membuat pola suku } \\
\text { terbuka tetap }\end{array}$ & 35 & 45 & 62 \\
\hline 12 & $\begin{array}{l}\text { Membuat pola suku } \\
\text { terbuka dan dapat } \\
\text { mengeja sebagian }\end{array}$ & 34 & 49 & 63 \\
\hline 13 & $\begin{array}{l}\text { Membuat pola suku } \\
\text { tertutup dan tetap, } \\
\text { dapat mangeja } \\
\text { sebagian }\end{array}$ & 33 & 45 & 63 \\
\hline 14 & $\begin{array}{l}\text { Membuat pola suku } \\
\text { tertutup dapat } \\
\text { mengeja }\end{array}$ & 32 & 47 & 59 \\
\hline 15 & $\begin{array}{l}\text { Membuat pola kata } \\
\text { tetap }\end{array}$ & 33 & 47 & 62 \\
\hline 16 & $\begin{array}{l}\text { Membuat pola kata } \\
\text { sendiri dan dapat } \\
\text { membacanya }\end{array}$ & 33 & 42 & 59 \\
\hline 17 & $\begin{array}{l}\text { Melanjutkan kata } \\
\text { kartu guru dan } \\
\text { dapat membacanya }\end{array}$ & 31 & 36 & 51 \\
\hline & JUMLAH & 612 & 785 & 1037 \\
\hline
\end{tabular}

Berdasarkan data tabel diatas dapat diketahui bahwa perkembangan keaksaraan anak kelompok B4 TK Negeri Pembina Yogyakarta semester 1 pada tahun ajaran 2011/2012 mengalami peningkatan. Kemampuan keaksaraan yang muncul antara lain anak dapat membuat pola suku kata tertutup dan dapat mengeja, anak dapat membuat pola kata sendiri dan dapat membacanya.

Tabel 2. Rekapitulasi Data Hasil Minat Baca

\begin{tabular}{|c|c|c|c|c|}
\hline \multirow{2}{*}{ No } & \multirow{2}{*}{ Responden } & \multicolumn{3}{|c|}{ Skor Hasil Tindakan } \\
\hline & & $\begin{array}{c}\text { Pra } \\
\text { Tindakan }\end{array}$ & $\begin{array}{l}\text { Siklus } \\
\text { I }\end{array}$ & $\begin{array}{c}\text { Siklus } \\
\text { II }\end{array}$ \\
\hline 1 & $\begin{array}{l}\text { Anak minta dibacakan } \\
\text { buku }\end{array}$ & 33 & 40 & 55 \\
\hline 2 & $\begin{array}{l}\text { Anak mengeja tulisan } \\
\text { yang ditemui ( apapun } \\
\text { hasilnya) }\end{array}$ & 34 & 50 & 64 \\
\hline 3 & $\begin{array}{l}\text { Anak melihat- lihat } \\
\text { gambar atau tulisan } \\
\text { dalam buku yang } \\
\text { disediakan }\end{array}$ & 38 & 48 & 62 \\
\hline 4 & $\begin{array}{l}\text { Anak menyimak } \\
\text { dengan baik cerita } \\
\text { yang dibacakan }\end{array}$ & 36 & 42 & 58 \\
\hline 5 & $\begin{array}{l}\text { Anak memperhatiakn } \\
\text { label atau mencoba } \\
\text { membacanya }\end{array}$ & 40 & 50 & 62 \\
\hline 6 & $\begin{array}{l}\text { Anak menirukan } \\
\text { orang membaca } \\
\text { apapun tahapnya }\end{array}$ & 39 & 48 & 64 \\
\hline 7 & $\begin{array}{l}\text { Anak antusias terlibat } \\
\text { kegiatan membaca } \\
\text { bersama guru dan } \\
\text { teman }\end{array}$ & 36 & 44 & 61 \\
\hline 8 & $\begin{array}{l}\text { Menanyakan isi } \\
\text { bacaan dalam buku } \\
\text { anak atau bacaan lain }\end{array}$ & 28 & 42 & 61 \\
\hline 9 & $\begin{array}{l}\text { Anak terlihat ingin } \\
\text { cepat bisa membaca }\end{array}$ & 33 & 42 & 61 \\
\hline 10 & $\begin{array}{l}\text { Anak suka terlibat } \\
\text { aktif dalam permainan } \\
\text { keaksaraan }\end{array}$ & 40 & 52 & 61 \\
\hline 11 & $\begin{array}{l}\text { Anak antusias } \\
\text { mengoleksi buku - } \\
\text { buku yang dipajang }\end{array}$ & 28 & 32 & 52 \\
\hline 12 & $\begin{array}{l}\text { Anak lebih suka } \\
\text { membuka-buka buku } \\
\text { saat istirahat }\end{array}$ & 28 & 32 & 49 \\
\hline 13 & $\begin{array}{l}\text { anak berani unjuk } \\
\text { kemampuan baca } \\
\text { (apapun hasilnya) }\end{array}$ & 36 & 42 & 56 \\
\hline 14 & $\begin{array}{l}\text { Anak antusias ketika } \\
\text { diajak ke } \\
\text { perpustakaan }\end{array}$ & 39 & 47 & 69 \\
\hline 15 & $\begin{array}{l}\text { Anak membantu } \\
\text { teman membaca }\end{array}$ & 30 & 32 & 52 \\
\hline 16 & $\begin{array}{l}\text { Anak melakukan } \\
\text { kegiatan membaca } \\
\text { (apapun hasilnya) } \\
\text { tanpa disuruh }\end{array}$ & 34 & 44 & 55 \\
\hline 17 & $\begin{array}{l}\text { Anak menanyakan } \\
\text { lafal atau simbol / } \\
\text { huruf yang ditemui }\end{array}$ & 38 & 44 & 63 \\
\hline & JUMLAH & 590 & 731 & 1005 \\
\hline
\end{tabular}

\section{KESIMPULAN}

Berdasarkan hasil penelitian yang dilaksanakan melalui beberapa tindakan, 
dari siklus I, dan siklus II di kelompok B4 TK Negeri Pembina Yogyakarta Semester I tahun ajaran 2011/ 2012, serta berdasarkan seluruh pembahasan dan analisis yang telah dilakukan, dapat disimpulkan bahwa kegiatan permainan pola suku kata dengan media kartu huruf telah mampu meningkatkan kemampuan keaksaraan anak terutama dalam minat baca, kemampuan reseptif membaca sambil bermain dan permainan pola suku kata anak.

1. Semakin sering kegiatan permainan pola suku kata dilakukan maka kemampuan keaksaraan reseptif anak dan minat baca anak akan mengalami peningkatan secara signifikan.

2. Kegiatan permianan pola suku kata dapat meningkatkan situasi belajar menjadi lebih kondusif dan menyenangkan sehingga pembelajaran menjadi lebih bermakna.

\section{Saran}

Adapun beberapa saran yang dapat disampaikan pada guru hendaknya guru TK perlu mencoba melaksanakan kegiatan ini dalam proses pembelajaran di TK masingmasing. Mengingat kurikulum yang digunakan pada saat ini memungkinkan bagi para guru TK untuk mengembangkan keaksaraan anak. Sedangakn untuk mengembangkan keaksaraan tersebut, kegiatan permainan pola suku kata dapat dilakukan oleh guru secara terprogram dan berkelanjutan untuk mendapatkan hasil yang lebih baik.

\section{DAFTAR PUSTAKA}

Departemen Pendidikan Nasional. 2007. Pedoman Pembelajaran Persiapan Membaca dan Menulis Melalui Permainan di Taman Kanak- Kanak. Jakarta : Depdiknas

Departemen Pendidikan Nasional. 2007. Pedoman Pembelajaran Bidang Pengembangan Berbahasa di Taman Kanak- Kanak. Jakarta : Depdiknas

Suharsimi Arikunto. 2010. Prosedur Penelitian Suatu Pendekatan Praktik.ed.rev. Jakarta: PT Rineka Cipta

Suharsimi Arikunto. 2009. Penelitian Tindakan Kelas.Jakarta: Bumi Aksara

Tadkiroatun $\quad$ Musfiroh. 2009. Menumbuhkembangkan Baca Tulis anak Usia Dini. Jakarta: PT Grasindo

Tadkiroatun Musfiroh. 2011. Permainan Keaksaraan Anak Usia Dini. Pusdi PAUD Lemlit UNY 